Supporting Information for

\title{
Tunable Luminescent Lanthanide Coordination Polymers Based on Reversible Solid-State Ion-Exchange Monitored by Ion-Dependent Photoinduced Emission Spectra
}

\author{
Peng Wang, Jian-Ping Ma, Yu-Bin Dong,* and Ru-Qi Huang
}

College of Chemistry, Chemical Engineering and Materials Science, Engineering Research Center of Pesticide and Medicine Intermediate Clean Production, Ministry of Education, Shandong Normal University, Jinan 250014, P. R. China. Email: yubindong@sdnu.edu.cn

\footnotetext{
* to whom correspondence should be addressed
} 


\section{Experimental Section}

\section{Material and measurements.}

The ligand was synthesized according to the literature method previously reported by us. ${ }^{1}$ $\mathrm{Ln}_{2}\left(\mathrm{SO}_{4}\right)_{3} \cdot 8 \mathrm{H}_{2} \mathrm{O}(\mathrm{Ln}=\mathrm{Gd}, \mathrm{Tb}, \mathrm{Eu}, \mathrm{La})$ were prepared by the reaction of $\mathrm{Ln}_{2} \mathrm{O}_{3}$ and $\mathrm{H}_{2} \mathrm{SO}_{4}$ aqueous solution. Infrared (IR) samples were prepared as $\mathrm{KBr}$ pellets, and spectra were obtained in the $400 \sim 4000 \mathrm{~cm}^{-1}$ range using a Bruker Tensor-27 FTIR spectrometer. Element analyses were performed on a Perkin-Elmer model 240C analyzer. All fluorescence measurement were carried out on a cary Eclipse Spectrofluorimeter (Varian, Australia) equipped with a xenon lamp and quartz carrier at room temperature. XRD pattern were obtained on a Rigaku D/Max-rB X-ray powder diffraction (XRD) with CuKa radiation ( $\lambda=1.5405 \&$ Aring). Synthesis of $\left\{\left[\left(\mathbf{L a}_{2} \mathbf{L}_{\mathbf{4}}\right) \mathbf{M n}\left(\mathbf{H}_{\mathbf{2}} \mathbf{O}\right)_{\mathbf{6}}\right] \cdot\left(\mathbf{H}_{\mathbf{2}} \mathbf{O}\right)\right\}_{\mathbf{n}}(\mathbf{1}): \mathbf{L}(0.019 \mathrm{mmol}), \mathrm{La}_{2}\left(\mathrm{SO}_{4}\right)_{3} \cdot 8 \mathrm{H}_{2} \mathrm{O}(0.015$ mmol), $\mathrm{MnSO}_{4} \cdot \mathrm{H}_{2} \mathrm{O}(0.079 \mathrm{mmol}$.) and water $(5 \mathrm{~mL})$ was sealed in a $20-\mathrm{ml}$ stainless-steel bomb with a teflon liner and was heated at $180^{\circ}$ for 76 hours under autogenous pressure. After the mixture was allowed to cool to room temperature (50 hours), colorless cubic crystals were isolated from the bomb. The resulted colorless crystalline solid was washed successively with hot DMF (5 mL×2) and water (5 mL×4), and dried in air. Yield: $79 \%$. IR: 3359(s), 1616(s), 1595(m), 1562(s), 1525(m), 1411(vs), 1389(s), 1293(m), 1121(w), 1077(w), 1002(w), 877(m), 774(s), 756(s), 722(s), 694(w), 683(w). Anal. Calc. for $\mathrm{La}_{2} \mathrm{MnC}_{64} \mathrm{H}_{54} \mathrm{~N}_{16} \mathrm{O}_{23}: \mathrm{C}, 43.97 ; \mathrm{H}, 3.11$; $\mathrm{N}, 12.82 \%$. Found: C, 43.81; H, 3.25; N, $13.06 \%$.

Synthesis of $\left\{\left[\left(\mathbf{G d}_{2} \mathbf{L}_{4}\right) \mathbf{M n}\left(\mathrm{H}_{2} \mathbf{O}\right)_{6}\right] \cdot \mathbf{0 . 5}\left(\mathrm{H}_{2} \mathrm{O}\right)\right\}_{\mathbf{n}}$ (2): The process was the same as that for $\mathbf{1}$ but used $\mathrm{Gd}_{2}\left(\mathrm{SO}_{4}\right)_{3} \cdot 8 \mathrm{H}_{2} \mathrm{O}$ rather than $\mathrm{La}_{2}\left(\mathrm{SO}_{4}\right)_{3} \cdot 8 \mathrm{H}_{2} \mathrm{O}$ as the starting material. Yield: $72 \%$. IR: 3361(s), 1620(s), 1596(m), 1565(s), 1529(m), 1416(vs), 1080(m), 1001(w), 882(m), 775(s), 
760(s), 723(s), 696(m), 685(w), 656(w). Anal. Calc. for $\mathrm{Gd}_{4} \mathrm{Mn}_{2} \mathrm{C}_{128} \mathrm{H}_{106} \mathrm{~N}_{32} \mathrm{O}_{45}: \mathrm{C}, 43.29 ; \mathrm{H}$, $3.01 ; \mathrm{N}, 12.62 \%$. Found: C, 43.19; H, 3.15; N, $12.96 \%$.

Synthesis of $\left\{\left[\left(\mathbf{E u}_{2} \mathbf{L}_{4}\right) \mathbf{M n}\left(\mathbf{H}_{2} \mathbf{O}\right)_{6}\right] \cdot \mathbf{0 . 5}\left(\mathbf{H}_{2} \mathbf{O}\right)\right\}_{\mathbf{n}}(3)$ : The process was the same as that for $\mathbf{1}$ but used $\mathrm{Eu}_{2}\left(\mathrm{SO}_{4}\right)_{3} \cdot 8 \mathrm{H}_{2} \mathrm{O}$ rather than $\mathrm{La}_{2}\left(\mathrm{SO}_{4}\right)_{3} \cdot 8 \mathrm{H}_{2} \mathrm{O}$ as the starting material. Yield: $70 \%$. IR: 3363(s), 1620(s), 1597(m), 1564(s), 1527(m), 1413(vs), 1269(m), 1167(w), 1078(w), 1001(w), 880(m), 775(s), 759(s), 722(s), 696(m), 684(w), 654(w). Anal. Calc. for $\mathrm{Eu}_{4} \mathrm{Mn}_{2} \mathrm{C}_{128} \mathrm{H}_{106} \mathrm{~N}_{32} \mathrm{O}_{45}$ : C, 43.55; H, 3.03; N, $12.70 \%$. Found: C, 43.70; H, 3.17; N, $12.96 \%$.

Synthesis of $\left\{\left[\left(\mathbf{T b}_{2} \mathbf{L}_{4}\right) \mathbf{M n}\left(\mathrm{H}_{2} \mathbf{O}\right)_{6}\right] \cdot \mathbf{0 . 5}\left(\mathbf{H}_{2} \mathbf{O}\right)\right\}_{\mathbf{n}}(\mathbf{4})$ : The process was the same as that for $\mathbf{1}$ but used $\mathrm{Tb}_{2}\left(\mathrm{SO}_{4}\right)_{3} \cdot 8 \mathrm{H}_{2} \mathrm{O}$ rather than $\mathrm{La}_{2}\left(\mathrm{SO}_{4}\right)_{3} \cdot 8 \mathrm{H}_{2} \mathrm{O}$ as the starting material. Yield: $73 \%$. IR: 3359(s), 1622(s), 1566(s), 1527(m), 1414(vs), 1269(m), 1078(w), 1001(w), 881(m), 774(s), 760(s), 722(s), 696(m), 684(w), 654(w). Anal. Calc. for $\mathrm{Tb}_{4} \mathrm{Mn}_{2} \mathrm{C}_{128} \mathrm{H}_{106} \mathrm{~N}_{32} \mathrm{O}_{45}: \mathrm{C}, 43.21 ; \mathrm{H}$, $3.00 ; \mathrm{N}, 12.60 \%$. Found: C, 43.30; H, 3.21; N, $12.86 \%$.

$\left\{\left[\left(\mathbf{G d}_{2} \mathbf{L}_{4}\right)\left(\mathbf{T b}\left(\mathbf{H}_{2} \mathbf{O}\right)_{8}\right)\left(\mathbf{C l O}_{4}\right)\right] \cdot \mathbf{0 . 5 H _ { 2 }} \mathbf{O}\right\}_{n}(\mathbf{5})$ : the crystals of $\mathbf{2}(23 \mathrm{mg})$ were stirred in an aqueous solution $(4 \mathrm{~mL})$ of $\mathrm{Tb}\left(\mathrm{ClO}_{4}\right)_{3} \cdot 6 \mathrm{H}_{2} \mathrm{O}$ (large excess) at room temperature for 7 days, the resulted colorless crystalline solid was collected and then was washed successively by water (5 $\mathrm{mL} \times 4)$ and $\mathrm{EtOH}(5 \mathrm{~mL} \times 2)$, and dried in air. IR: 3354(s), 1619(s), 1594(m), 1562(s), 1528(m), 1415(vs), 1249(m), 1097(m), 1081(w), 1004(w), 884(m), 777(s), 759(s), 722(s), 680(w). Anal. Calc. for $\mathrm{Gd}_{4} \mathrm{~Tb}_{2} \mathrm{C}_{128} \mathrm{H}_{114} \mathrm{Cl}_{2} \mathrm{~N}_{32} \mathrm{O}_{57}: \mathrm{C}, 38.14 ; \mathrm{H}, 2.85 ; \mathrm{N}, 11.12 \%$. Found: $\mathrm{C}, 38.63 ; \mathrm{H}, 2.59 ; \mathrm{N}$, $11.49 \%$.

$\left\{\left[\left(\mathbf{G d}_{2} \mathbf{L}_{4}\right)\left(\mathbf{E u}\left(\mathrm{H}_{2} \mathbf{O}\right)_{\mathbf{8}}\right)\left(\mathbf{C l O}_{4}\right)\right] \cdot \mathbf{0 . 5} \mathbf{H}_{2} \mathbf{O}\right\}_{\mathbf{n}}(\mathbf{6}): \mathbf{5}(20 \mathrm{mg})$ was stirred in an aqueous solution (4 $\mathrm{mL}$ ) of $\mathrm{Eu}\left(\mathrm{ClO}_{4}\right)_{3} \cdot 6 \mathrm{H}_{2} \mathrm{O}$ (large excess) at room temperature for 7 days, the resulted colorless crystalline solid was collected and washed by water $(5 \mathrm{~mL} \times 4)$ and $\mathrm{EtOH}(5 \mathrm{~mL} \times 2)$, and 
dried in air. IR: 3359(s), 1620(s), 1597(m), 1563(s), 1529(m), 1416(vs), 1269(m), 1168(w), 1078(w), 1003(w), 881(m), 775(s), 758(s), 722(s), 696(m), 684(w). Anal. Calc. for $\mathrm{Gd}_{4} \mathrm{Eu}_{2} \mathrm{C}_{128} \mathrm{H}_{114} \mathrm{Cl}_{2} \mathrm{~N}_{32} \mathrm{O}_{57}$ : C, 38.28; H, 2.86; N, $11.16 \%$. Found: C, 38.69; H, 2.53; N, 11.59 $\%$.

Single-Crystal Structure Determination. Suitable single crystals of complexes $\mathbf{1}$ - $\mathbf{4}$ were selected and mounted in air onto thin glass fibers. X-ray intensity data were measured at 293(2) K on a Bruker SMART APEX CCD-based diffractometer (Mo K $\alpha$ radiation, $\lambda=0.71073 \AA$ ). The raw frame data for 1-4 were integrated into SHELX-format reflection files and corrected for Lorentz and polarization effects using SAINT. ${ }^{2}$ Corrections for incident and diffracted beam absorption effects were applied using SADABS. ${ }^{2}$ None of the crystals showed evidence of crystal decay during data collection. All structures were solved by a combination of direct methods and difference Fourier syntheses and refined against $\mathrm{F}^{2}$ by the full-matrix least squares technique. Crystal data, data collection parameters, and refinement statistics for 1- $\mathbf{4}$ are listed in Table S1-4.

\section{The ORTEP Figures of 1-4.}



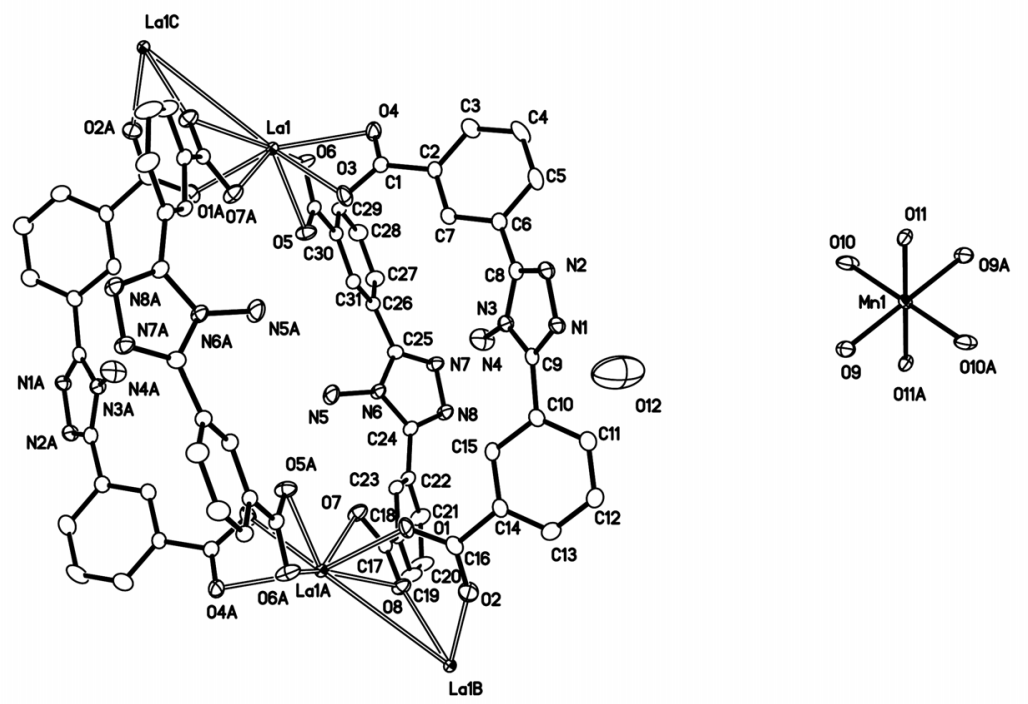

Figure S1. The ORTEP figure of $\mathbf{1}$ (Displacement ellipsoids drawn at the $30 \%$ probability level).

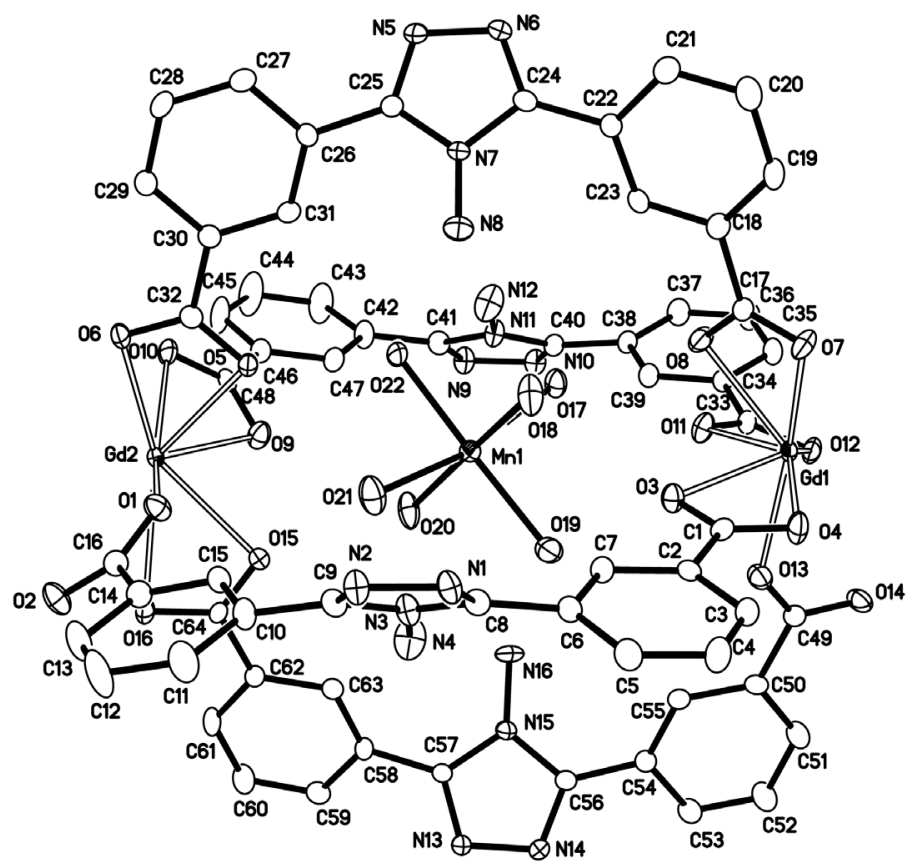

Figure S2. The ORTEP figure of $\mathbf{2}$ (Displacement ellipsoids drawn at the $30 \%$ probability level). 


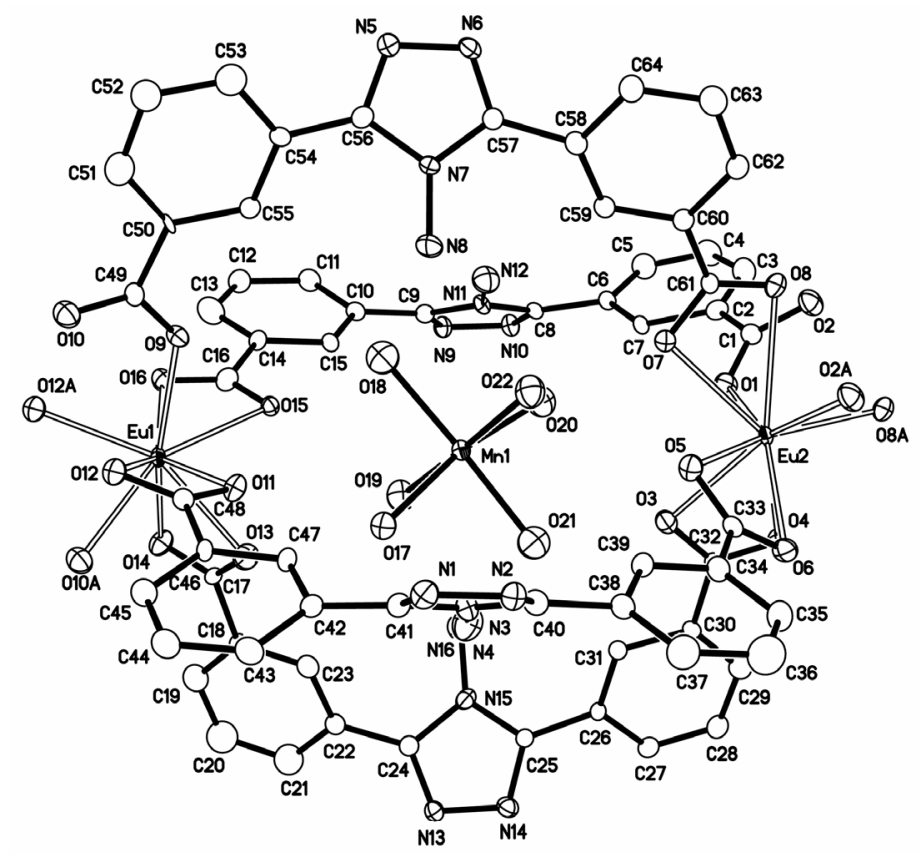

Figure S3. The ORTEP figure of $\mathbf{3}$ (Displacement ellipsoids drawn at the $30 \%$ probability level).

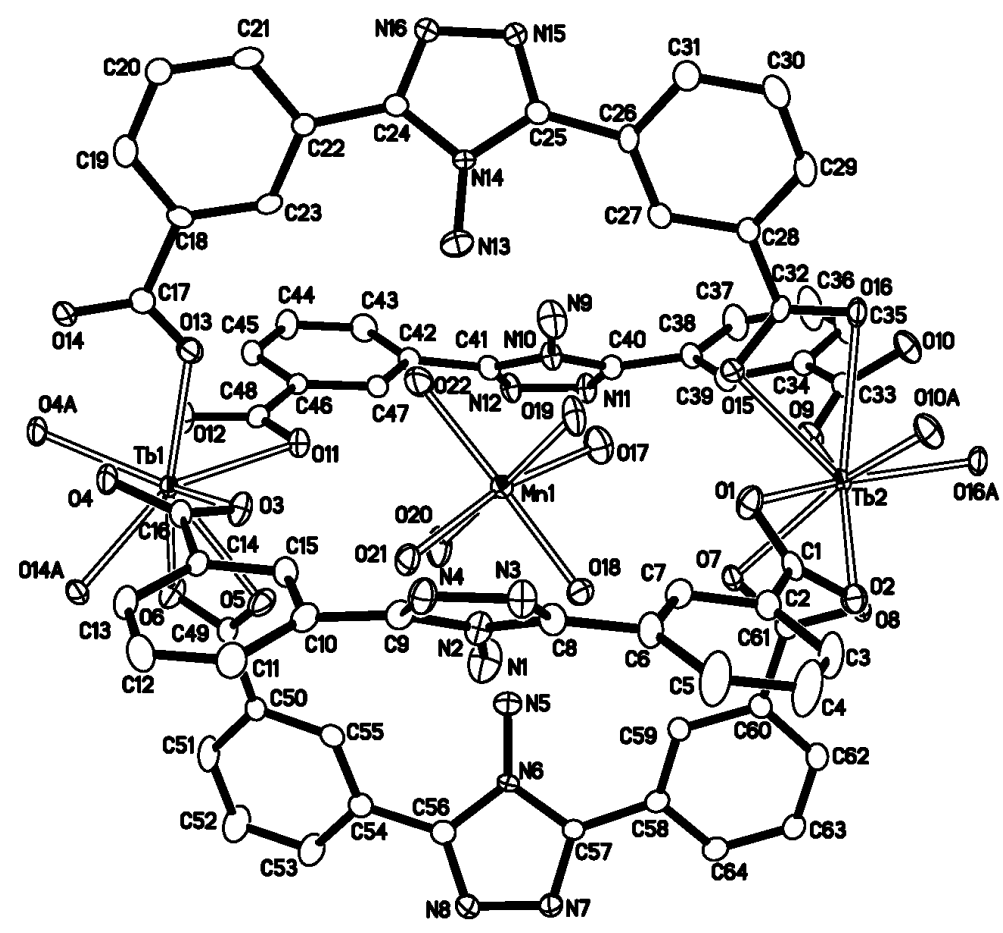

Figure S4. The ORTEP figure of 4 (Displacement ellipsoids drawn at the $30 \%$ probability level). 


\section{Photoinduced Emission Spectra of 1-4.}
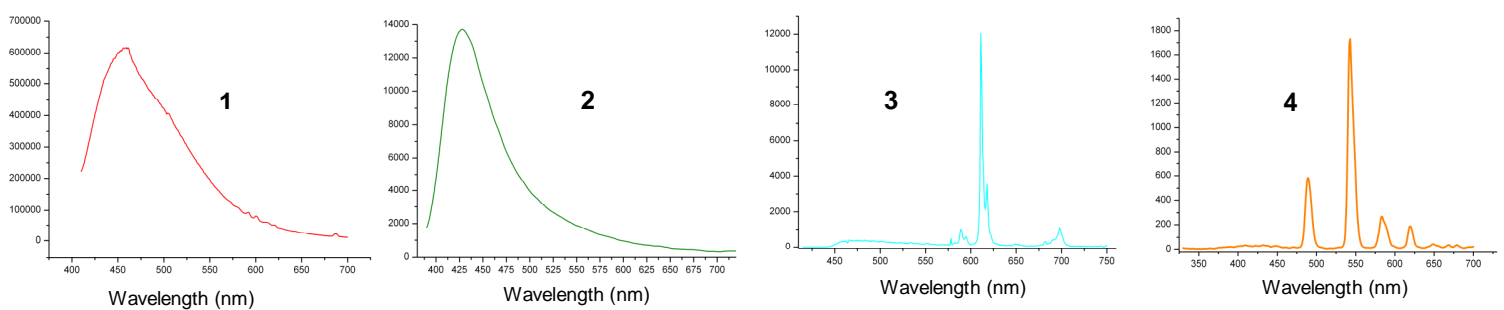

Figure S5. Photoinduced emission spectra of $\mathbf{1}\left(\lambda_{\mathrm{ex}}=397 \mathrm{~nm}\right), \mathbf{2}\left(\lambda_{\mathrm{ex}}=368 \mathrm{~nm}\right), \mathbf{3}\left(\lambda_{\mathrm{ex}}=395 \mathrm{~nm}\right)$ and $\mathbf{4}\left(\lambda_{\mathrm{ex}}=\right.$ $303 \mathrm{~nm}$ ) in the solid state.

\section{X-ray Powder Diffraction Patterns of 2, 5, 6 and Regenerated of 2.}
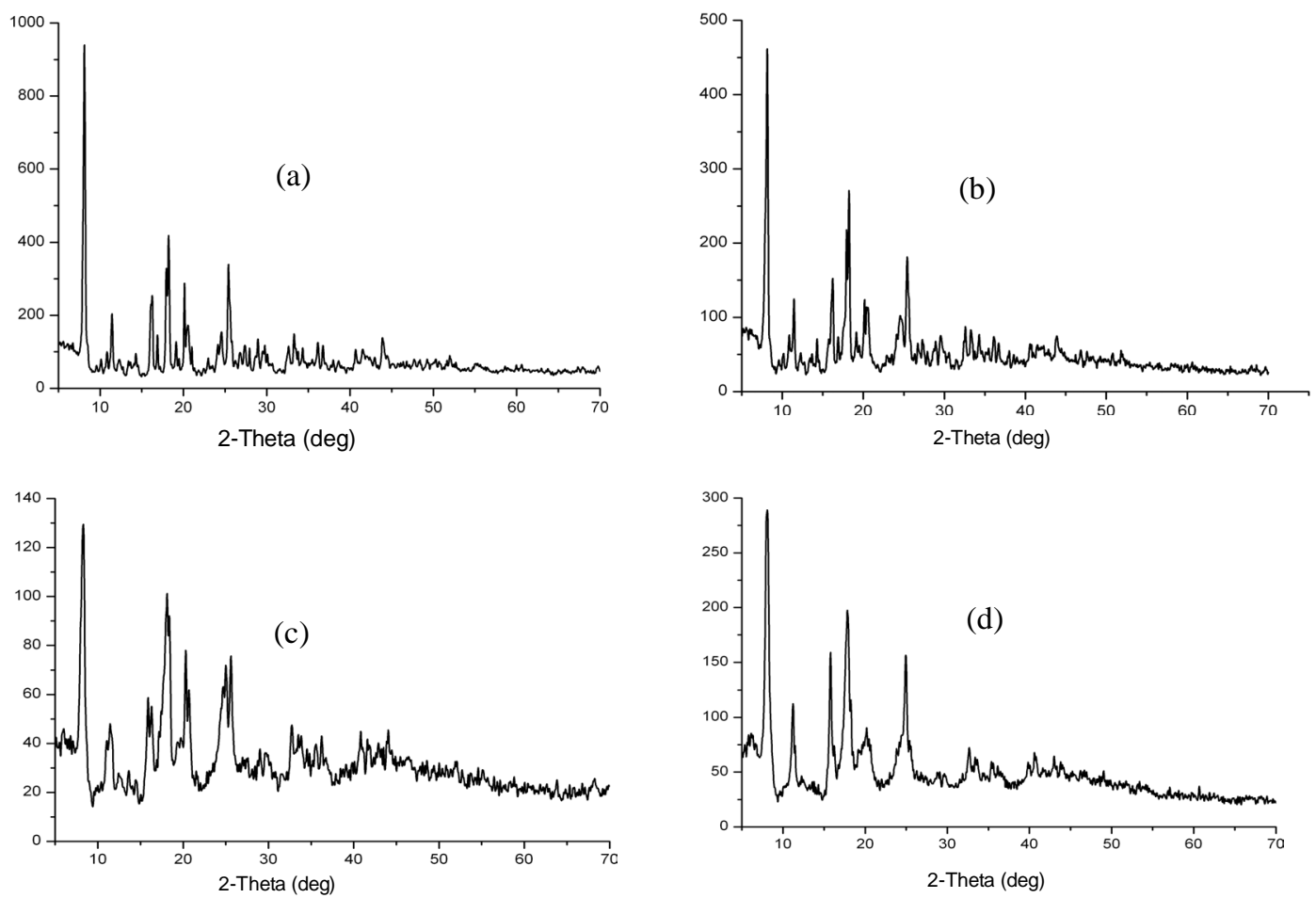

Figure S6. (a)-(d): X-ray powder diffraction patterns of $\mathbf{2 , 5 , 6}$ and regenerated of 2 (2'). 


\section{Solubility of Compounds 1-4.}

Compounds 1-4 are completely insoluble in water due to their polymeric natures. When the single crystals of these complexes were immersed in water for around one month, their single crystallinity still maintained, and the single-crystal analysis revealed that the structures are identical to the original ones. These complexes are insoluble in acidic solution, but crack and turn opaque. The XRD patterns indicated that the complexes lost their original structures (Fig. S7). In basic aquo solution, the compounds decomposed and $\mathrm{Ln}(\mathrm{OH})_{3}$ precipitated.
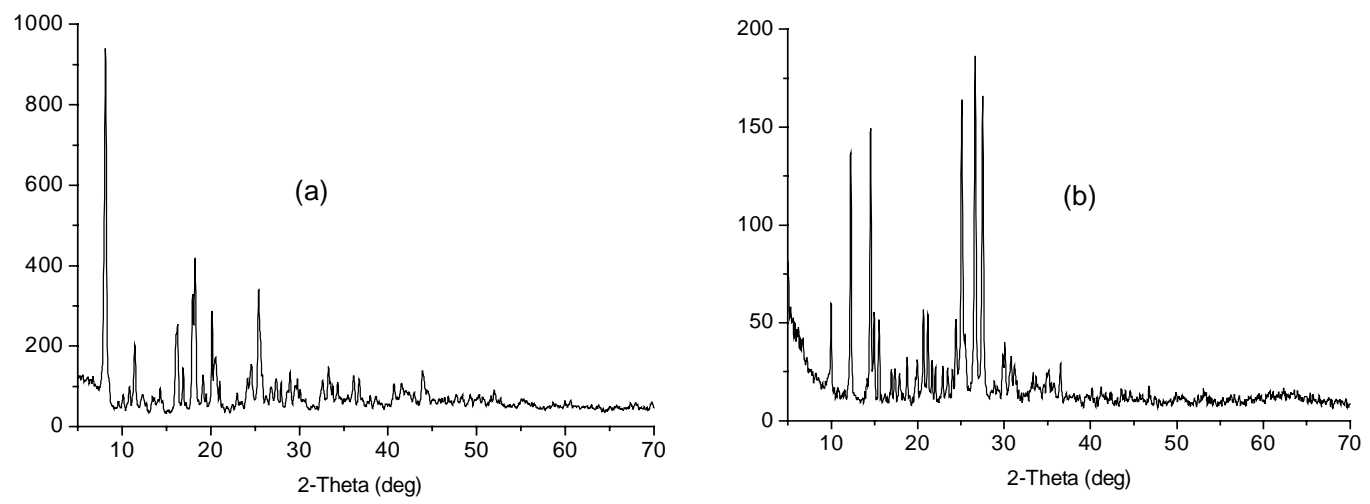

Figure S7. The XRD patterns of 2: (a) the original crystals of 2; (b) The crystals of $\mathbf{2}$ were immersed in acidic solution $(\mathrm{pH}=1)$ for three hours.

\section{The Thermal Stability of Compounds 1-4.}
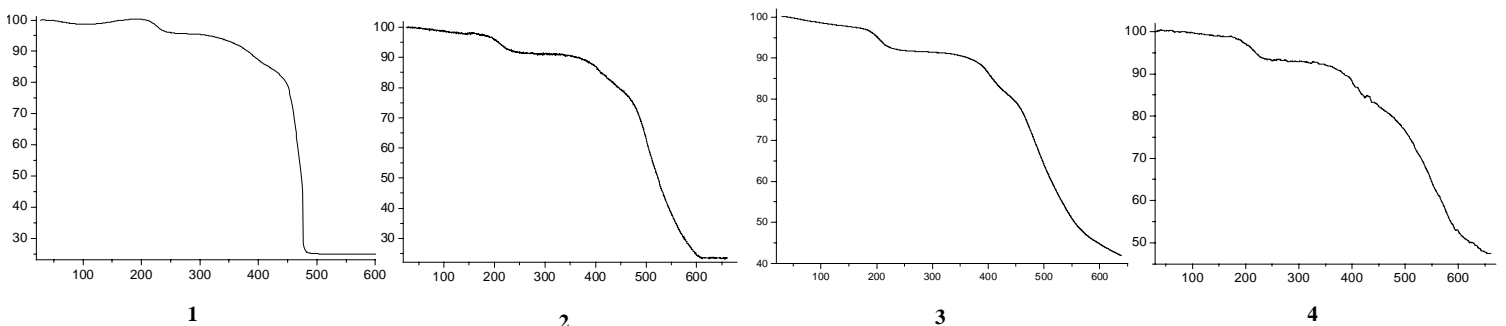

Figure S8. The TGA traces of 1-4. Thermogravimetric analyses were carried out using a TA Instrument SDT 2960 simultaneous DTA-TGA under flowing nitrogen at a heating rate of $15^{\circ} \mathrm{C} / \mathrm{min}$. X-and Y-axes mean temperature $\left({ }^{\circ} \mathrm{C}\right)$ and weight loss $(\%)$, respectively. As indicated in the figure, compounds 1-4 exhibit similar thermal decomposition behavior due to their identical structural feature. The guest water molecules in 1-4 were lost up to $150^{\circ} \mathrm{C}$ and the coordinated water molecules were lost above $226^{\circ} \mathrm{C}$. The polymer frameworks of 1-4 collapsed when the coordinated water molecules were lost (Fig. S9). 

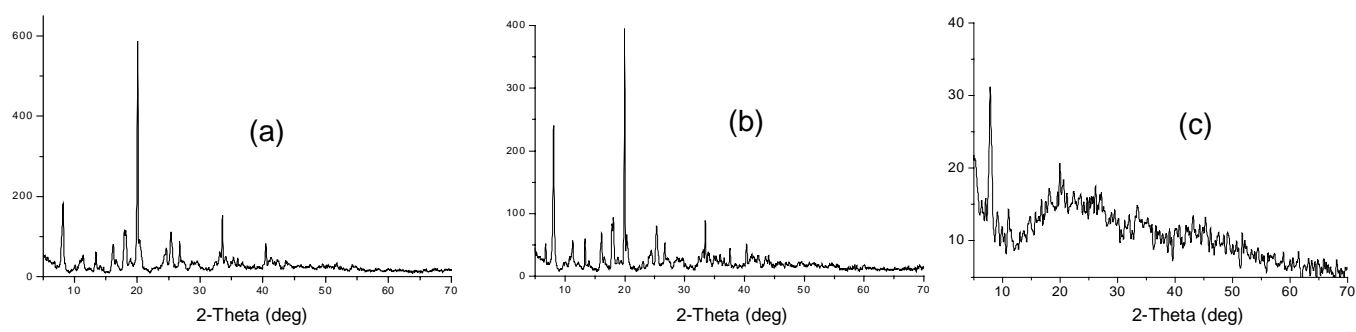

Figure S9. X-ray powder patterns of 1: (a) the original crystals of $\mathbf{1}$; (b) $\mathbf{1}$ heated to $170^{\circ} \mathrm{C}$; (c) $\mathbf{1}$ heated to $260^{\circ} \mathrm{C}$.

The Control Experiment of Ion-Exchange Reactions Based on Different Ln(III) Salts.

Besides the $\mathrm{Ln}\left(\mathrm{ClO}_{4}\right)_{3}$, the $\mathrm{LnCl}_{3}$ or $\mathrm{Ln}\left(\mathrm{NO}_{3}\right)_{3}$ can also be used to perform the ion-exchange reactions, but take a longer time. This is probably because of the stronger coordination nature caused by the $\mathrm{Cl}^{-}$or $\mathrm{NO}_{3}{ }^{-}$anion (Fig. S10).

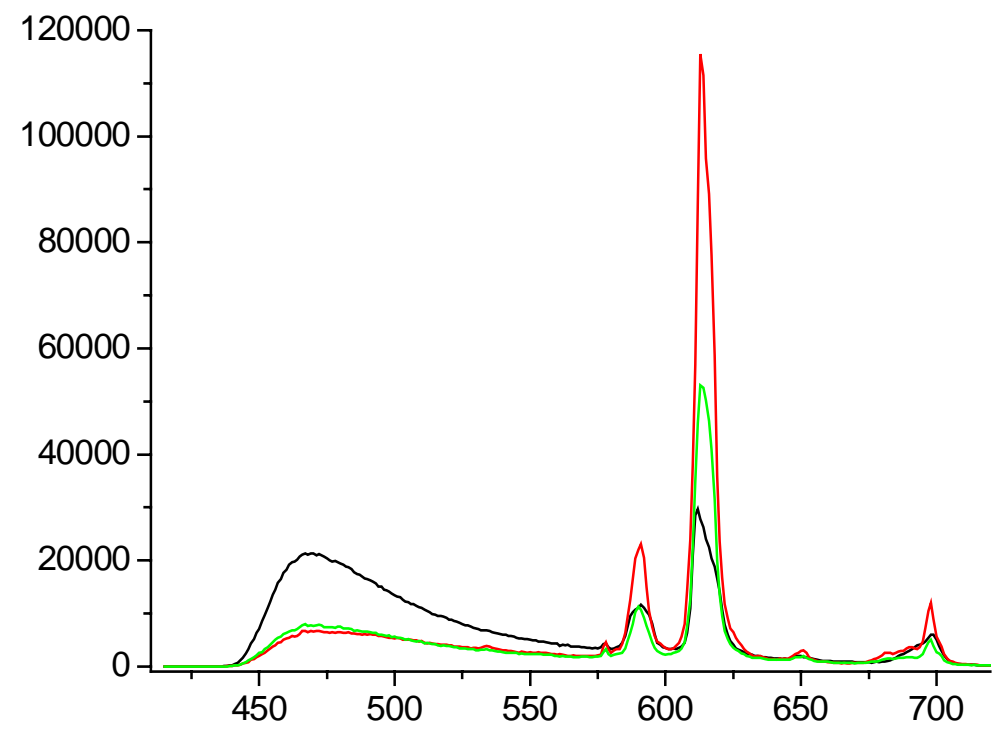

Figure S10. Guest-exchanging process of cation species based on 2: the solid-state emission spectra of 2 stirred in a $\mathrm{Eu}\left(\mathrm{ClO}_{4}\right)_{3}$ (red), $\mathrm{EuCl}_{3}$ (green) or $\mathrm{Eu}\left(\mathrm{NO}_{3}\right)_{3}$ (black) aqueous solution at 2 days. 
Table S1. Crystal data and structure refinement for $\mathbf{1}$.

\begin{tabular}{|c|c|}
\hline Identification code & 1 \\
\hline Empirical formula & C64 H54 La2 Mn N16 O23 \\
\hline Formula weight & 1747.99 \\
\hline Temperature & $298(2) \mathrm{K}$ \\
\hline Wavelength & $0.71073 \mathrm{~A}$ \\
\hline Crystal system, space group & Triclinic, P-1 \\
\hline \multirow[t]{3}{*}{ Unit cell dimensions } & $\mathrm{a}=11.0587(12) \mathrm{A} \quad$ alpha $=76.8040(10) \mathrm{deg}$ \\
\hline & $\mathrm{b}=11.3607(13) \mathrm{A} \quad$ beta $=84.6520(10) \mathrm{deg}$ \\
\hline & $\mathrm{c}=13.9423(15) \mathrm{A} \quad$ gamma $=89.4380(10) \mathrm{deg}$ \\
\hline Volume & $1697.8(3) \mathrm{A}^{\wedge} 3$ \\
\hline Z, Calculated density & $1,1.710 \mathrm{Mg} / \mathrm{m}^{\wedge} 3$ \\
\hline Absorption coefficient & $1.511 \mathrm{~mm}^{\wedge}-1$ \\
\hline $\mathrm{F}(000)$ & 873 \\
\hline Crystal size & $0.34 \times 0.26 \times 0.20 \mathrm{~mm}$ \\
\hline Theta range for data collection & 1.84 to $25.50 \mathrm{deg}$ \\
\hline Limiting indices & $-11<=\mathrm{h}<=13,-11<=\mathrm{k}<=13,-16<=\mathrm{l}<=16$ \\
\hline Reflections collected / unique & $8890 / 6175[\mathrm{R}(\mathrm{int})=0.0210]$ \\
\hline Completeness to theta $=25.50$ & $97.5 \%$ \\
\hline Absorption correction & Semi-empirical from equivalents \\
\hline Max. and min. Transmission & 0.7521 and 0.6276 \\
\hline Refinement method & Full-matrix least-squares on $\mathrm{F}^{\wedge} 2$ \\
\hline Data / restraints / parameters & $6175 / 0 / 484$ \\
\hline Goodness-of-fit on $\mathrm{F}^{\wedge} 2$ & 1.078 \\
\hline Final $\mathrm{R}$ indices [I>2sigma(I)] & $\mathrm{R} 1=0.0367, \mathrm{wR} 2=0.0953$ \\
\hline $\mathrm{R}$ indices (all data) & $\mathrm{R} 1=0.0388, w \mathrm{R} 2=0.0965$ \\
\hline Largest diff. peak and hole & 1.204 and -0.643 e. $\mathrm{A}^{\wedge}-3$ \\
\hline
\end{tabular}


Table S2. Crystal data and structure refinement for $\mathbf{2}$.

\begin{tabular}{|c|c|}
\hline Identification code & 2 \\
\hline Empirical formula & C128 H106 Gd4 Mn2 N32 O45 \\
\hline Formula weight & 3551.33 \\
\hline Temperature & $298(2) \mathrm{K}$ \\
\hline Wavelength & $0.71073 \mathrm{~A}$ \\
\hline Crystal system, space group & Triclinic, $\mathrm{P}-1$ \\
\hline \multirow[t]{2}{*}{ Unit cell dimensions } & $\begin{array}{ll}\mathrm{a}=11.1220(11) \mathrm{A} & \text { alpha }=79.7440(10) \mathrm{deg} \\
\mathrm{b}=11.1502(11) \mathrm{A} & \text { beta }=86.1500(10) \mathrm{deg}\end{array}$ \\
\hline & $\mathrm{c}=27.107(3) \mathrm{A} \quad$ gamma $=89.9920(10) \mathrm{deg}$ \\
\hline Volume & $3300.2(6) \mathrm{A}^{\wedge} 3$ \\
\hline Z, Calculated density & $1,1.787 \mathrm{Mg} / \mathrm{m}^{\wedge} 3$ \\
\hline Absorption coefficient & $2.269 \mathrm{~mm}^{\wedge}-1$ \\
\hline $\mathrm{F}(000)$ & 1764 \\
\hline Crystal size & $0.20 \times 0.16 \times 0.07 \mathrm{~mm}$ \\
\hline Theta range for data collection & 0.77 to $25.03 \mathrm{deg}$. \\
\hline Limiting indices & $-12<=\mathrm{h}<=13,-12<=\mathrm{k}<=13,-27<=1<=32$ \\
\hline Reflections collected / unique & $16846 / 11481[\mathrm{R}(\mathrm{int})=0.0228]$ \\
\hline Completeness to theta $=25.03$ & $98.4 \%$ \\
\hline Absorption correction & Semi-empirical from equivalents \\
\hline Max. and min. transmission & 0.8573 and 0.6597 \\
\hline Refinement method & Full-matrix least-squares on $\mathrm{F}^{\wedge} 2$ \\
\hline Data / restraints / parameters & $11481 / 18 / 949$ \\
\hline Goodness-of-fit on $\mathrm{F}^{\wedge} 2$ & 1.018 \\
\hline Final $R$ indices [I>2sigma(I)] & $\mathrm{R} 1=0.0380, \mathrm{wR} 2=0.1011$ \\
\hline $\mathrm{R}$ indices (all data) & $\mathrm{R} 1=0.0465, \mathrm{wR} 2=0.1058$ \\
\hline Largest diff. peak and hole & 1.583 and -0.550 e. $A^{\wedge}-3$ \\
\hline
\end{tabular}


Table S3. Crystal data and structure refinement for 3 .

\begin{tabular}{|c|c|}
\hline Identification code & 3 \\
\hline Empirical formula & C128 H104 Eu4 Mn2 N32 O44 \\
\hline Formula weight & 3512.15 \\
\hline Temperature & 298(2) K \\
\hline Wavelength & $0.71073 \mathrm{~A}$ \\
\hline Crystal system, space group & Triclinic, $\mathrm{P}-1$ \\
\hline \multirow[t]{3}{*}{ Unit cell dimensions } & $\mathrm{a}=11.139(3) \mathrm{A} \quad$ alpha $=79.687(5) \mathrm{deg}$ \\
\hline & beta $=86.145(4)$ deg. \\
\hline & $\mathrm{c}=27.170(8) \mathrm{A} \quad$ gamma $=89.942(5) \mathrm{deg}$. \\
\hline Volume & $3313.2(17) \mathrm{A}^{\wedge} 3$ \\
\hline Z, Calculated density & $1,1.760 \mathrm{Mg} / \mathrm{m}^{\wedge} 3$ \\
\hline Absorption coefficient & $2.150 \mathrm{~mm}^{\wedge}-1$ \\
\hline $\mathrm{F}(000)$ & 1750 \\
\hline Crystal size & $0.18 \times 0.12 \times 0.10 \mathrm{~mm}$ \\
\hline Theta range for data collection & 0.76 to $25.01 \mathrm{deg}$. \\
\hline Limiting indices & $-13<=\mathrm{h}<=12,-13<=\mathrm{k}<=10,-32<=\mathrm{l}<=31$ \\
\hline Reflections collected / unique & $16594 / 11427[\mathrm{R}(\mathrm{int})=0.0419]$ \\
\hline Completeness to theta $=25.01$ & $97.7 \%$ \\
\hline Absorption correction & Semi-empirical from equivalents \\
\hline Max. and min. transmission & 0.8137 and 0.6982 \\
\hline Refinement method & Full-matrix least-squares on $\mathrm{F}^{\wedge} 2$ \\
\hline Data / restraints / parameters & 11427 / $636 / 946$ \\
\hline Goodness-of-fit on $\mathrm{F}^{\wedge} 2$ & 1.293 \\
\hline Final $R$ indices $[\mathrm{I}>2 \operatorname{sigma}(\mathrm{I})]$ & $\mathrm{R} 1=0.1244, \mathrm{wR} 2=0.2636$ \\
\hline $\mathrm{R}$ indices (all data) & $\mathrm{R} 1=0.1365, \mathrm{wR} 2=0.2694$ \\
\hline Largest diff. peak and hole & 3.180 and -4.000 e. $\mathrm{A}^{\wedge}-3$ \\
\hline
\end{tabular}


Table S4. Crystal data and structure refinement for 4.

\begin{tabular}{|c|c|}
\hline Identification code & 4 \\
\hline Empirical formula & C128 H106 Mn2 N32 O45 Tb4 \\
\hline Formula weight & 3558.01 \\
\hline Temperature & $298(2) \mathrm{K}$ \\
\hline Wavelength & $0.71073 \mathrm{~A}$ \\
\hline Crystal system, space group & Triclinic, $\mathrm{P}-1$ \\
\hline \multirow[t]{3}{*}{ Unit cell dimensions } & $\mathrm{a}=11.1188(16) \mathrm{A} \quad$ alpha $=79.742(2) \mathrm{deg}$. \\
\hline & $\mathrm{b}=11.1414(16) \mathrm{A} \quad$ beta $=86.224(2) \mathrm{deg}$. \\
\hline & $\mathrm{c}=27.065(4) \mathrm{A} \quad$ gamma $=89.898(2) \mathrm{deg}$ \\
\hline Volume & $3291.9(8) \mathrm{A}^{\wedge} 3$ \\
\hline Z, Calculated density & $1, \quad 1.795 \mathrm{Mg} / \mathrm{m}^{\wedge} 3$ \\
\hline Absorption coefficient & $2.408 \mathrm{~mm}^{\wedge}-1$ \\
\hline $\mathrm{F}(000)$ & 1768 \\
\hline Crystal size & $0.28 \times 0.23 \times 0.11 \mathrm{~mm}$ \\
\hline Theta range for data collection & 0.77 to $25.02 \mathrm{deg}$. \\
\hline Limiting indices & $-13<=\mathrm{h}<=11,-12<=\mathrm{k}<=13,-32<=1<=23$ \\
\hline Reflections collected / unique & $16209 / 11425[\mathrm{R}(\mathrm{int})=0.0215]$ \\
\hline Completeness to theta $=25.02$ & $98.1 \%$ \\
\hline Absorption correction & Semi-empirical from equivalents \\
\hline Max. and min. transmission & 0.7776 and 0.5520 \\
\hline Refinement method & Full-matrix least-squares on $\mathrm{F}^{\wedge} 2$ \\
\hline Data / restraints / parameters & 11425 / 24 / 958 \\
\hline Goodness-of-fit on $\mathrm{F}^{\wedge} 2$ & 1.041 \\
\hline Final $\mathrm{R}$ indices [I $>2 \operatorname{sigma}(\mathrm{I})]$ & $\mathrm{R} 1=0.0394, \mathrm{wR} 2=0.0988$ \\
\hline $\mathrm{R}$ indices (all data) & $\mathrm{R} 1=0.0461, \mathrm{wR} 2=0.1023$ \\
\hline Largest diff. peak and hole & 1.481 and -0.589 e. $A^{\wedge}-3$ \\
\hline
\end{tabular}

\section{Reference}

1. Wang, P.; Ma, J.-P.; Huang, R.-Q.; Dong, Y.-B. Acta Cryst. 2006. E62, o2791.

2. (a) SMART Version 5.625 and SAINT+ Version 6.02a. Bruker Analytical X-ray Systems, Inc., Madison, Wisconsin, USA, 1998. (b) ldrick, G. M. SHELXTL Version 5.1; Bruker Analytical X-ray Systems, Inc., Madison, Wisconsin, USA, 1997. 